\title{
DISTRIBUTIVE IMPACT OF CZECH SOCIAL SECURITY AND TAX SYSTEMS: DYNAMICS IN EARLY $2000 S$
}

\author{
Ondřej SCHNEIDER, Tomáš JELÍNEK*
}

\begin{abstract}
:
In this paper, we analyse the Czech social and tax systems and their impact on income distribution. We use regular household surveys, organized and published by the Czech Statistical Office (CSO), for years 1999 - 2002. This longer time span allows us to identify some trends in the Czech social security system and their impact on well-being of various income groups. We find that while the total cost of the Czech social security system were not escalating in the period of $1999-2002$, the illness benefit - already the largest spending programme - rose by enormous $72 \%$ in these four years. This largesse failed, however, to improve income of the poorest households as the benefit is very inefficient in increasing income of the poorest households. We also find that spending on more focused programmes (social supplement and parental allowance) increased least. Last but not least, we analysed the impact of tax deductions on the income distribution in the Czech Republic. These deductions represent a massive transfer, comparable to all social benefits combined. Our analysis shows, that the impact of tax deductions on income of the poorest decile fell significantly over the period of $1999-2002$.
\end{abstract}

Keywords: public budgets, social policy, income distribution

JEL Classification: D61, H55, I38

\section{Introduction}

In this paper we continue our research into the Czech social and tax systems and their impact on income distribution. An introductory study on this subject was published in 2001 in which we examined in detail the social and tax systems and their impact on poverty in the Czech Republic (see Schneider, Jelínek, 2001). In that

*) Institute of Economic Studies, Faculty of Social Sciences, Charles University, Opletalova 26, CZ 11000 Prague 1; Institute of Social and Economic Analyses, ISEA, K červenému dvoru 6, CZ - 16000 Prague 6 (e-mail: schneider@fsv.cuni.cz; jelinek@isea-cz.org).

$\left.{ }^{* \star}\right)$ This research has been supported by a grant from the Czech Grant Agency No. 402/2004 and by the Faculty of Social Sciences' Research Programme for the $2005-2009$. We would like to thank Gabriela Hrubá of the IES FSV UK for an excellent research support and Petra Štěpánková of Raiffaisen Bank for discussions and useful comments. The responsibility for all omissions and errors is, however, solely of us. 
paper we focused on a single year 1999 as we did not have longer series of data. In this paper we use regular household surveys, organized and published by the Czech Statistical Office (CSO), for 1999 - 2002. This longer time span allows us to identify some trends in the Czech social security system and their impact on well-being of various income groups. Namely, our goal is to show the impact of social benefits and income tax deductible allowances on income distribution in the Czech Republic and cost of these programmes (see Schneider, 2001, pp. 655).

As we noted in the 2001 paper, "targeting of majority of social programs [in 1999] is quite good. More than one fourth of all goes to households in the lowest income decile. Three fourth of all expenses goes to households in the lower half of income spectrum".

In this paper, we find that while the total costs of the Czech social security system were not escalating in the period 1999 - 2002, the illness benefit - already the largest spending programme - rose by enormous $72 \%$ in these four years, as the benefit was made more generous in 2000 . This largesse, costing the state budget as much as CZK 28 bill in 2002, failed, however, to improve income of the poorest households. We also find that spending on more focused programmes (social supplement and parental allowance) rose the least while the worst focused programmes (unemployment and illness benefits) rose faster (significantly faster in the case of illness benefits).

Last but not least, we analysed the impact of tax deductions on the income distribution in the Czech Republic. These deductions represent a massive transfer, comparable to all social benefits combined. Tax deductions, due to the Czech system whereby deductions were made from the tax base, not the tax due, were less effective in redistributing to poor households. Our analysis moreover shows, that the impact of tax deductions on income of the poorest decile fell significantly over the period $1999-2002$.

The paper is organized as follows: in the first section, we briefly describe the Czech social security system and its cost in the period $1999-2002$. In the second chapter, we look at the effects of the system on the income of typified Czech households. In the third chapter we turn to the microeconomic data and discuss merits of the household survey data and their developments in the analysed period. The fourth chapter adds tax deductions to the discussion. The fifth chapter presents the analysis of the distributive impact of various social benefits on Czech households. The sixth chapter presents a discussion of budgetary cost of these programmes and the following chapter attempts to measure efficiency of various programmes and their developments in the period $1999-2002$. We close the paper by brief conclusions and tentative policy recommendations.

\section{Social Security System in the Czech Republic}

The new social system was created in the early 1990s as a social safety net for everyone in need. When analysing social security we concentrate on following social benefits: child allowance, social supplement, parental allowances, other social benefits, unemployment benefits and illness benefit as they are included in the household budget survey. ${ }^{1)}$ Here analysed benefits imply state expenditures of more

1) In order to limit the scope of the analysis, we have left out most of the social insurance system, such as old-age and invalidity pensions, the whole range of benefits for disabled persons as these have many specific features and aims. 
than CZK 55 bill. in 1999 rising to almost CZK 75 bill. in 2002. As a share in GDP it represented $3.0 \%$ in 1999 rising eventually to $3.3 \%$ in 2002 . The first four items are formally part of social support system, while unemployment benefit and illness benefit are part of social security system. The social support system has the direct goal to increase income of the poorest groups in society and it is naturally subject of our concern. The social security system plays double role: on the one side it imitates insurance, when higher contributions generate higher benefits, on the other side computation of benefits is so much distorted that "social insurance" is more an another tool for social redistribution than some type of insurance and we thus include it in our analysis. ${ }^{2)}$

The state social support, created in 1995, consists of nine different benefits, three of them means-tested, five untested and one combined (see below). The benefits might be separated into two main groups: those supporting families (child allowances, parental allowances, social allowance for childcare) and those aimed at poor families (social supplement, various housing benefits). Besides, there are two untested benefits, as to illustrate the cradle-to-crave approach of the Czech social security system: birth and funeral benefits. From the fiscal point of view, child allowances were easily the biggest scheme, with annual costs around CZK 13 bill., followed by the parental allowances (CZK 8 bill.) and social supplement (approx. CZK 6 bill.). The remaining schemes are marginal in fiscal terms, but perhaps substantial in social terms.

The whole construction of the social support allowances is based on the legal minimum living standards (MLS). Minimum living standards serve as a basis for both the determination of the income levels up to which the allowance is due, and the determination of the amount of allowance (in terms of the fixed multiples of the minimum living standards). This way, both the levels of benefits and the eligibility criteria are automatically indexed whenever minimum living standards are changed.

\section{Means-tested Family Benefits:}

a) Children allowances - supplementary income for the purpose of raising a child. Annual costs in 1999 were CZK 12.5 bill. Since January 1993, the amount of the monthly allowance has been a function of the age of a child, ranging from CZK 340 (for a child under six years of age) to CZK 490 (for a child over 15 years of age). ${ }^{3)}$ Since October 1995, the size of the benefit has depended also on the household income.

Families with income of up to triple of the minimum living standard for their type of family are eligible for some allowance. If the total income is less than $110 \%$ of minimum living standard (MLS) for their family type, the benefit equals $32 \%$ of the child's MLS for each dependent child. Families with income in the range of $110-$ $180 \%$ of MLS are eligible for $28 \%$ of the child's MLS for each dependent child. Families with income in the range $180-300 \%$ of the MLS are eligible for $14 \%$ of the child's MLS for each dependent child. Entitlement lasts as long as the child is dependent. A parent has to re-apply each year and his/her income during the preceding year is tested. A dependent child is defined as any unmarried child under the

2) The same could be said about old-age pension system, which are the biggest social programmes in all OECD countries. For its size and specific purpose we do not include it in our analysis.

3) Before 1993 the allowance was a function of the total number of children in the family, where the marginal increment was positive. 
age of 26 years as long as he/she is a student in a defined type of secondary or higher educational institution or cannot (due to a long-term illness or disability) earn any income. Until the age of 18 also a registered unemployed not receiving unemployment benefits is considered to be a dependent child. ${ }^{4}$ )

b) Social supplement when caring for a child - additional supplementary income for the purpose of raising a child paid to a family with at least one dependent child and having an income below $160 \%$ of the MLS. Entitlement: a parent has to re-apply quarterly; income of the preceding quarter is tested. The level of the benefit is defined as follows: ${ }^{5}$

$$
\mathrm{SA}=\mathrm{MLS} 1-\frac{\mathrm{MLS} 1 * \mathrm{I}}{\mathrm{MLS} 2{ }^{*} 1.6}
$$

where: SA = social allowance when caring for a child, MLS1 = sum of individual minimum living standards of all dependent children, MLS2 = minimum living standard of a family (sum of individual standards and household minimum), $I=$ family income

c) Housing allowances - A household is eligible when the joint income of all persons permanently residing in a flat falls below $140 \%$ of the MLS for this type of a household, irrespective of the ownership type of the flat (also inhabitants of the self-owned flats are eligible) and irrespective of the actual housing expenses. A household has to re-apply quarterly and the income of the preceding quarter is tested. The level of the benefit is scaled to three income bands, i.e. whether family income falls below $100 \%, 120 \%$ or $140 \%$ of the MLS.

d) Transportation benefit - is a benefit introduced after the subsidies to pupil and student transport fares were phased out and it is partly means tested and partly untested. Any dependent child studying in a municipality different from his/her permanent residence municipality is eligible. Families, where children did not complete compulsory schooling (9 years), are eligible for the benefit irrespective of the family income. If a dependent child studies at the secondary or higher educational institution, only a family with income below $200 \%$ of the MLS is eligible. Construction of the benefit level is based on the price of public transport and the resulting sum depends on the type of a school attended and regularity of transportation (daily, weekly, etc.). Entitlement is established yearly.

Transportation benefit is seen as the most administrative complicated and probably not well targeted benefit (no data are available, as the benefit is not observed by the household surveys (see below). Thus, costs of the scheme - almost CZK 1 bill. in 1999 - are difficult to measure against any measurable outcome.

\section{Non-tested Family Benefits:}

a) Parental allowance - a payment to a parent caring personally full-time for a child 4 years old or younger or for a handicapped child under the age of 7 which is not placed in nursery, kindergarten or any other institution for preschool children. The

4) The child allowances are formally means-tested but in reality $90 \%$ of families qualify for a benefit and roughly $50 \%$ for the highest category of benefits. They are paid until 26 years if a child keeps studying. The child allowances are often combined with the social supplement that is more targeted at poor but it is not clear why to have two programmes at all.

5) The benefit is scaled up further when either the children or the parents are ill with a long-term illness or disabled, or when the household is formed by a single parent (the scaling coefficients are different for each situation). 
parent is eligible for the benefits unless he/she receives health insurance, unemployment benefits or maternity leave benefits. Until 2004, the parent might have earned the sum lower or equal to his/her personal minimum living standard at most in order to qualify for the benefit. ${ }^{6)}$ The size of the benefit was defined as $110 \%$ of the personal MLS of the parent. ${ }^{7}$ )

b) Benefit at the birth of a child - is a one-time benefit provided upon the birth of a child. The size of the benefit is a multiple of the individual MLS of a newly born child and depends on a number of children born simultaneously, rising nonlinearly. ${ }^{8)}$

c) Lump sum funeral benefit - is paid to a person that organized a funeral and is fixed at 5,000 CZK.

All of the social support benefits are non-taxable but are included in the income of a household applying for the income support under the system of social assistance.

\section{The Unemployment Compensation System}

An unemployment compensation system was put into effect on January 1, 1990 and it has undergone several changes since. It began as a generous one until reforms put into place on January 1, 1992 made the level of benefits (based on wage replacement rates) and eligibility criteria more restrictive. In January 1996, new reforms increased the replacement rates for the new entrants and certain other groups of unemployed and widened again the eligibility criteria.

In January 1, 1996 the base for the maximum changed to the minimum living standard for an adult in a one-person household and currently the ceiling is $250 \%$ of the MLS (290\% of the MLS for unemployed attending a retraining course). There is no minimum benefit since $1992 .{ }^{9)}$ Benefits are not indexed to inflation, nor are they taxed.

\section{IIIness Benefits}

IIIness benefits substitute lost income during short illness. They are financed from a special surcharge on the payroll tax and are redistributive in nature, as their level is topped. An ill worker is entitled to the benefits from the very first day of his/her illness and there is no cost-sharing by employers. It is no surprise, thus, that the system is often used for short-term off-loading of unneeded workers. On average, $7 \%$ of workers claim an illness on a working day in the Czech Republic.

The benefit formula is rather complex, as it calculates the daily benefit level from average gross income in the last three months. While first CZK 360 of the daily income comes fully into the formula, only $60 \%$ of the income in the CZK $360-540$ does and income above the CZK 540 daily (CZK 16 thousand monthly, or $150 \%$ of the 1999 average wage) is forfeited completely when the illness benefit is calculated. The benefit then equals to $69 \%$ of the adjusted income $(50 \%$ for first three

6) As of 2004 , this provision was scrapped and the parental benefit is no longer tested on parents' income. Parents must not, however, put their children to a permanent, state sponsored kindergarten.

7) The parental benefit is particularly long (four years). Long tenure of the benefits was meant to shield women from high unemployment but as any deformation of the labour market disadvantage women who often find it difficult to return to the labour market after raising one or even two children. Therefore, the system lowers labour force at high costs to the taxpayer.

8) $400 \%$ of the child's MLS when one child was born, $500 \%$ of the child's MLS when two children were born and $900 \%$ of the child MLS when three or more children were born.

9) The unemployed are eligible to the minimum living standards, as discussed above. 
days). The costs of the illness benefit system, together with other social programmes, are summarized below in the Table 1.

Table 1

Cost of Selected Social Security Programmes (CZK bill., current prices)

\begin{tabular}{|l|c|c|c|c|c|c|}
\hline & $\begin{array}{c}\text { Child } \\
\text { allowance }\end{array}$ & $\begin{array}{c}\text { Social } \\
\text { supplement }\end{array}$ & $\begin{array}{c}\text { Parental } \\
\text { allowance }\end{array}$ & $\begin{array}{c}\text { Other } \\
\text { social } \\
\text { allowance }\end{array}$ & $\begin{array}{c}\text { Illness } \\
\text { benefits }\end{array}$ & $\begin{array}{c}\text { Unemploy- } \\
\text { ment } \\
\text { benefits }\end{array}$ \\
\hline 1999 & 12.500 & 6.251 & 7.718 & 4.000 & 16.467 & 5.700 \\
\hline 2000 & 12.748 & 6.199 & 7.692 & 5.038 & 23.716 & 5.680 \\
\hline 2001 & 12.799 & 6.041 & 7.701 & 6.055 & 25.716 & 5.229 \\
\hline 2002 & 13.353 & 6.271 & 8.022 & 6.050 & 28.318 & 6.210 \\
\hline $\begin{array}{l}\text { Index 2002 } \\
\text { to } 1999 \text { (in \%) }\end{array}$ & 106.8 & 100.3 & 103.9 & 151.3 & 172.0 & 108.9 \\
\hline
\end{tabular}

Source: Ministry of Labour and Social Affairs, government budgets.

\section{Effects of the System}

It is not easy to assess the combined effects of various social programmes, as benefits are often means-tested and always depend on the family size. However, in order to understand the system impact on the Czech labour market and the efficiency of the system, it is necessary to model its functioning.

We have thus constructed two "typical families" consisting of two adults and two children (or one child only). A two-child family is entitled to a series of benefits: first it gets children allowances if its income is not above $300 \%$ of MLS. If the family

Figure 1

Social Benefits of a Family of Four (CZK for multiples of MLS)

Social benefits, family $2+2$ (CZK monthly)

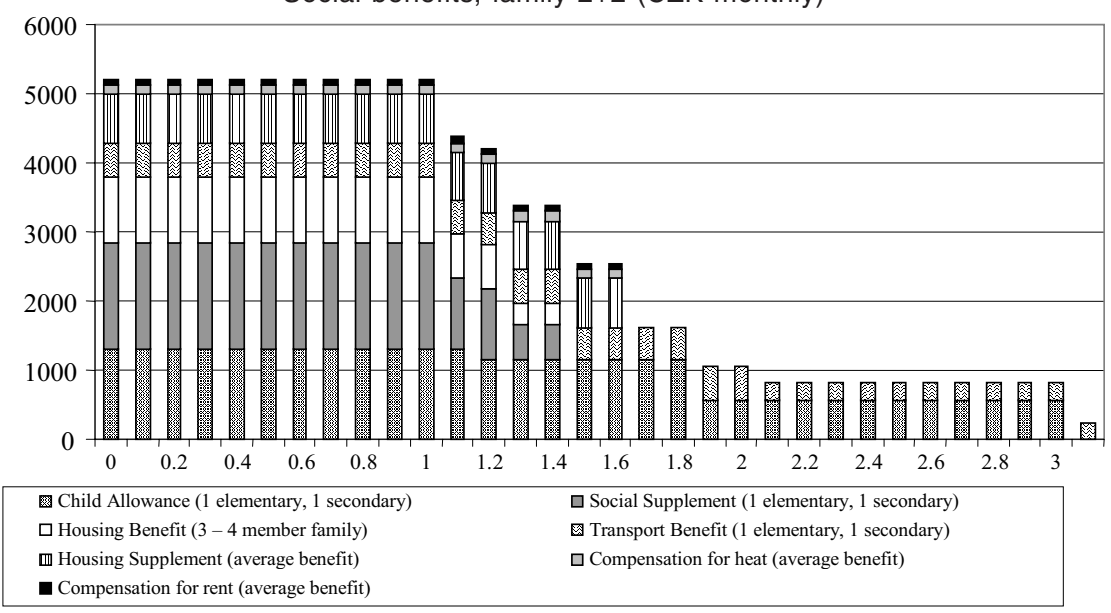

Note: The figure does not reflect the "top-up" component of the social system that tops income of this model family to CZK 11,030 .

Source: Authors' calculations. 
income is below $140 \%$ of MLS, it is entitled to the social supplement and housing benefit. Until its income is below $160 \%$ of MLS, the family gets also further "housing supplement". The younger child is entitled to a transportation benefits no matter what the family income is, the older, however, gets this benefit only if the family income is lower than $200 \%$ of the MLS. Altogether, the family could receive as many as seven different benefits of the state social support system (we leave aside the social insurance system). Of course, if the social support benefits are not sufficient to lift the family above the minimum living standard, its income is topped by the social assistance to reach the MLS.

The complexity of social benefits as just described deforms obviously incentives to work, as raising the family income above some of thresholds eliminates some social benefits. "Imputed tax rate", i.e. the rate at which social benefits are withdrawn when work income rises is as high as $100 \%$ for income up until $50 \%$ of the family MLS. In other words, all work income lower than $50 \%$ of the family MLS is "100\% compensated" by withdrawing social benefits.

Only after this threshold is reached, the family may actually boost its income by accepting a job, however, the average "withdrawn rate" remains high and gets to $50 \%$ when the work income reaches MLS. It remains at this level until the work income crosses the national average wage and only then slowly declines further (see Figure 2). On top of it, the marginal withdrawn rate reaches as much as $80 \%$ as various benefits are withdrawn at 1.2, 1.4, 1.6, 1.8, 2.0 and finally 3 multiples of the MLS. The average "withdrawn rate" hovers around $50 \%$ well until the work income reaches 2 MLS.

Figure 2

Withdrawal "Tax" Rates for a Family of Four (\% for multiples of MLS)

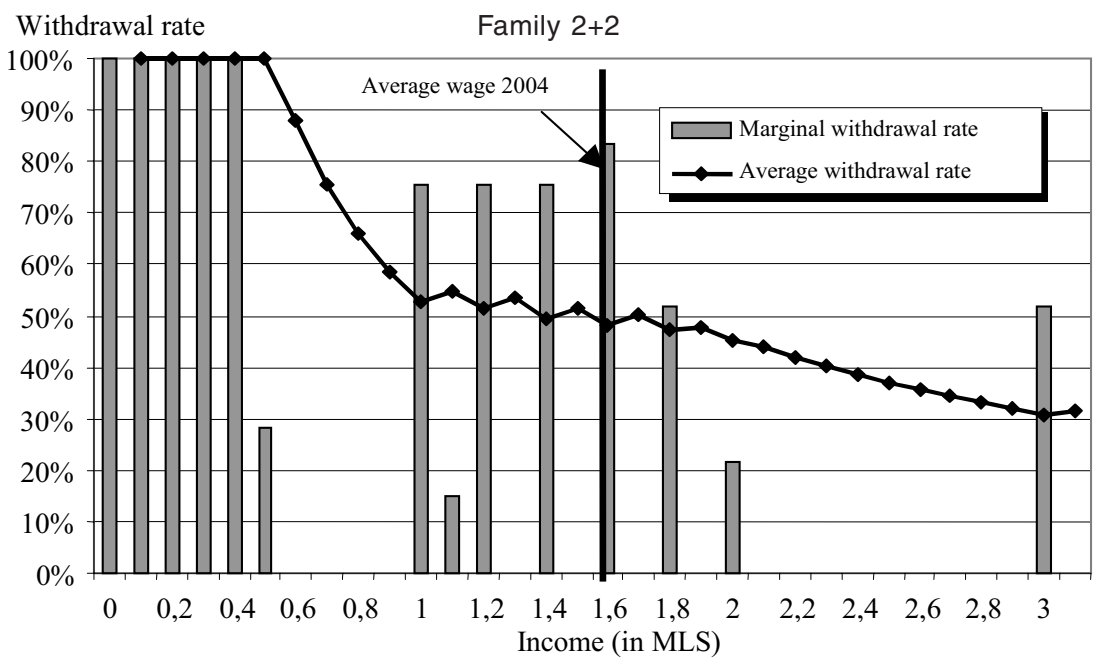

Source: Authors' calculations.

It seems, thus, fair to say that the effects of the social assistance and social support are quite detrimental for the work incentives, especially for bigger families who face drastic "withdrawal rates" when they seek a job. Please note that we take the wage in net terms, i.e. after income tax and social contributions were paid. While low wage may be tax-exempt (see below more on tax credits), social contributi- 
ons are paid from each wage and reach $47.5 \%$ of the before-the-tax wage (out of which $12.5 \%$ is paid by the employee and $35 \%$ by the employer). This further complicates employment of low-skilled workers.

\section{Statistical Dat a}

In order to get representative data on households' income we use the household survey, a regular and long-term panel study of more than 3,000 Czech households provided by the Czech Statistical Office (CSO). Despite the fact that this survey is mainly concerned with household consumption we believe it can be used for analysing income distribution of Czech households, even though we are aware that they are not strictly representative. Household budget survey, for example, does not include households where the head is unemployed or where the head is retired but other members are employed. ${ }^{10}$

The household survey is conducted on a monthly basis and for our purposes we used the 1999 - 2002 period - the most recent available. The survey is representative with respect to the income, age, social status and number of children. Thus, it is very likely representative with respect to many social benefits, as they are mostly based on the income status of the family or on the number of children in the family. The one benefit that should be treated carefully is the illness benefit, as there is no

Table 2

Main Social Benefits, Number of Recipients and Average Benefits (1999 data $^{1)}$, in CZK)

\begin{tabular}{|c|c|c|c|c|c|c|c|c|c|c|c|c|c|c|}
\hline & \multicolumn{2}{|c|}{$\begin{array}{c}\text { Child } \\
\text { allowances }\end{array}$} & \multicolumn{2}{|c|}{$\begin{array}{c}\text { Social } \\
\text { supplement }\end{array}$} & \multicolumn{2}{|c|}{$\begin{array}{c}\text { Parental } \\
\text { allowances }\end{array}$} & \multicolumn{2}{|c|}{$\begin{array}{l}\text { Other social } \\
\text { support }\end{array}$} & \multicolumn{2}{|c|}{$\begin{array}{c}\text { Unemployment } \\
\text { benefits }\end{array}$} & \multicolumn{2}{|c|}{ Illness benefits } & \multicolumn{2}{|c|}{ Tax allowances } \\
\hline & Number & $\begin{array}{c}\text { Av. } \\
\text { benefit }\end{array}$ & Number & $\begin{array}{c}\text { Av. } \\
\text { benefit }\end{array}$ & Number & $\begin{array}{c}\text { Av. } \\
\text { benefit }\end{array}$ & Number & $\begin{array}{c}\text { Av. } \\
\text { benefit }\end{array}$ & Number & $\begin{array}{c}\text { Av. } \\
\text { benefit }\end{array}$ & Number & $\begin{array}{c}\text { Av. } \\
\text { benefit }\end{array}$ & Number & $\begin{array}{c}\text { Av. } \\
\text { benefit }\end{array}$ \\
\hline D1 & 185 & 4,205 & 147 & 4,004 & 94 & 8,780 & 135 & 2,470 & 33 & 4,751 & 117 & 5,615 & 226 & 5,413 \\
\hline $\mathrm{D} 2$ & 160 & 3,843 & 96 & 2,389 & 63 & 9,269 & 93 & 1,850 & 31 & 5,016 & 102 & 5,648 & 207 & 5,704 \\
\hline D3 & 144 & 3,690 & 58 & 1,916 & 44 & 9,102 & 64 & 1,258 & 22 & 4,728 & 97 & 4,832 & 206 & 6,008 \\
\hline D4 & 149 & 3,609 & 33 & 1,001 & 31 & 7,528 & 57 & 1,561 & 16 & 2,614 & 114 & 4,379 & 218 & 6,192 \\
\hline D5 & 110 & 3,481 & 20 & 1,133 & 21 & 6,274 & 49 & 1,267 & 13 & 2,950 & 99 & 5,391 & 204 & 6,260 \\
\hline D6 & 111 & 3,167 & 8 & 343 & 10 & 7,324 & 28 & 1,059 & 15 & 4,811 & 115 & 3,883 & 212 & 6,476 \\
\hline D7 & 81 & 2,568 & 3 & 562 & 8 & 6,628 & 16 & 1,804 & 13 & 3,527 & 114 & 3,558 & 208 & 6,724 \\
\hline D8 & 42 & 2,203 & 2 & 1,250 & 2 & 11,597 & 15 & 1,797 & 11 & 4,229 & 107 & 4,263 & 203 & 6,767 \\
\hline D9 & 29 & 2,040 & 2 & 2,512 & 9 & 6,004 & 11 & 3,135 & 12 & 2,798 & 96 & 5,075 & 203 & 6,927 \\
\hline D10 & 7 & 2,211 & 1 & 1,678 & 3 & 8,796 & 5 & 2,616 & 3 & 3,059 & 90 & 2,949 & 202 & 7,944 \\
\hline & 1,018 & & 370 & & 285 & & 473 & & 169 & & 1,051 & & 2,089 & \\
\hline
\end{tabular}

1) Average benefit is calculated as an average from those households actually receiving the benefit. Source: Household Survey, own calculations.

10) According to some researchers - (e.g. J.Večerník,1998) - the household budget survey does not reflect proper income differentiation in the Czech society. 
apparent link to characteristics that are being targeted by the household survey. However, as the Table 2 shows, half of households typically receive the benefit at some point. Moreover, beneficiaries are evenly distributed among all deciles, so the illness benefits seem to be widespread and thus the survey covers them in a proper manner. We have excluded, however, a variable "other social assistance" that was received by mere $3 \%$ of the sample and in some deciles it was almost non-existent. The benefit had a little impact on overall distribution. Nevertheless, it was important for families who were actually receiving it.

As we were mainly concerned with distribution impact of the social security system (and tax credits as well) we used a constructed "market income" as a base for sorting households. The "market income" is calculated from the household survey where the reported net income is adjusted for received social transfers and for paid taxes. The resulting "market income" should simulate income the household would have had if there had been no government taxes and transfers. We should note, though, that taxes paid include in our concept also social contributions. In this respect, we had to recalculate social contributions paid by employees, as they report only a part of the social contributions as the bulk is "paid for" by employers. In fact, though, the whole tax burden is employees' so we have increased their paid taxes by amount of social contributions paid by their employers. ${ }^{11)}$ The survey covers households (as opposed to individuals) but it provides extensive demographic and income statistics, so it is rather straightforward to construct a distribution of incomes on individual basis, as we assume that all family members have the same share in the family income. It is often argued that larger families enjoy "returns to scale" as some household expenses are similar for one-member family and for more numerous families. To that extent, the CSO provides "weights" of additional family members: while the first member counts for one unit, the remaining adults for 0.7 and children of age $0-13$ for 0.5 of the unit. We used this "adjusted consumption scale" in our calculations.

While this survey probably underweights both the richest households (that have little incentive to cooperate with the CSO) and the poorest households (that are difficult to reach and that may find the CSO questionnaires too complicated), it does provide the most comprehensive and complex set on information households' incomes and expenditures.

\section{Tax Deductible Allowances}

The Czech tax code is often blamed for too high complexity and unnecessary high number of loopholes. However, compared to the other more developed countries tax codes, the Czech one is still in its infancy. However, the state does extend tax credits to some preferred activities: thus interest paid on mortgage is tax deductible, some fringe benefits are tax free (transport subsidies, catering, pension insurance and since 2001 also life insurance). There are various income groups that qualify for a tax credit; however, from the point of view of the social security only few make any impact.

Tax deductible allowances are called "tax expenditures" in the economic literature, because a tax-payer saves money through this mechanism. We could get the same result if the total income is taxed and "tax deductible allowance" would be paid directly from the state budget. But the tax-deductible allowance is considered to be

11) Note, that self-employed pay (and report) the whole social contributions, so we needed no adjustment in those cases where the household head was self-employed. 
more efficient and administratively friendly tool. Tax deductible allowance brings higher nominal gain to higher income groups, because it lowers their tax in higher tax brackets. ${ }^{12)}$

Most important are tax credits: on own "needs" on children and dependent spouses, summarized in Table 3. These benefits are, as the whole Czech tax system, exclusively individual, i.e. any member of a family can claim them, but on his/her income only. Their fiscal costs are substantial, albeit only estimated. Using very simple model, ${ }^{13)}$ we estimate that the individual tax-deductible allowances were worth CZK 33 bill. in 1999 and 2000 and about CZK 36 bill. in 2001 and 2002. Children and spouse tax deductible allowances cost the state budget further CZK 17 bill. It is, thus, important to look at the tax allowances' distributive aspects as well.

Table 3

Main Tax Allowances and Their Cost (CZK bill. annually)

\begin{tabular}{|l|r|r|r|r|}
\hline & 1999 & 2000 & 2001 & 2002 \\
\hline Individual tax credit & 33.3 & 33.0 & 36.1 & 36.3 \\
\hline Child credit & 10.4 & 11.0 & 10.8 & 10.6 \\
\hline Spouse credit & 4.8 & 4.7 & 5.0 & 4.9 \\
\hline Total cost & 48.5 & 48.8 & 51.9 & 51.8 \\
\hline
\end{tabular}

Source: Ministry of Finance, own estimates.

Clearly, these tax credits are regressive in nature, but their distribution impact is rarely analysed. Given the fact that the Czech tax system is progressive with marginal rate rising from $0 \%$ to $32 \%$ (and to $40 \%$ until 2000) the tax credits distribute disproportionate benefits to the well-off. Their administration, it is claimed, is cheaper than the social security's and they do not discourage from accepting a formal employment. However, there has been no analysis as to what extent these tax credits fulfill government goals in social policy.

\section{Redistribution Effects of the System}

In our analysis we tried to show a) how efficient various social programmes in lifting net income of households are, b) what the costs of this are. The following Table 4 summarizes our results concerning increase in net income of ten deciles of households. The household survey distinguishes six social security schemes: child allowances, social supplement, parental allowances, unemployment benefits and a group of other social support. We also add the tax-deductible allowance, although this is a special programme treated separately.

As the following table shows, in general terms the Czech social security system is rather well targeted at the poorest decile whose income was boosted by $30-40 \%$ in various years. The system was less generous to the second poorest decile that

12) If each individual can deduct CZK 34,920 from its labour income, an individual in the highest tax bracket of $40 \%$ saves little less than CZK 14,000. An individual in the lowest tax bracket of $15 \%$ would save only a little more than CZK 5,000.

13) We estimated budgetary costs of individual allowances using the labour force statistics. The children and spouse allowances were estimated using the number of children and the average number of children in a family. 
gets "only" 12 - $19 \%$ increase in income. The third decile gets an $8-12 \%$ boost. The boost then uniformly decreases to about $5 \%$ for the fifth decile and eventually to about $1 \%$ for the richest decile.

The dynamics of the system's redistribution function is rather complex. Year 2000 was marked by a massive shift vis-à-vis 1999 towards the poorest decile: its income boost increased by more than 5 percentage points. At the same year, all deciles but the richest one received a lesser boost in their incomes from the combined social benefits, the biggest loser being the second decile that lost almost 7 percentage points. These changes were driven mainly by the illness benefits developments, but the second decile lost in all social benefits (most surprising and dramatic is the collapse of unemployment benefit - while in 1999, $21 \%$ of total unemployment benefits went to the second poorest decile, in 2000 it was only $7 \%$ ).

In the following year 2001 , the poorest decile fared much worse: its income rose after social transfers by less than $30 \%$, due to the uniform fall of all social benefits. The second poorest decile recovered a little, mainly due to higher illness benefits. Other deciles lost again, marking the year as the least generous in the analysed period.

The last year in our sample, 2002, saw a small improvement for all deciles, most pronounced for the second and the third decile whose incomes were increased by social benefits by $16.3 \%$ and $10.4 \%$ respectively, i.e. by almost 3 percentage points more than in 2001. As always, the illness benefits were behind higher social benefits in 2002.

When we compare various social programmes, we may identify three rather well targeted programmes and three wider spread schemes. Best "targeted" social programmes are the social supplement and the parental allowance scheme. The social supplement advances income of the poorest decile by $5-6 \%$ and all but ignores the six richest deciles altogether. However, the social supplement was somewhat losing its income-increasing power vis-à-vis the poorest decile (it lifted its income by $6.1 \%$ in 1999 but only by $4.6 \%$ in 2002). Perhaps surprisingly, the parental allowance scheme is targeted very well: it moved up income of the poorest decile by 5$8 \%$ and the second decile's income by about $3 \%$, making little impact elsewhere. But again, the poorest decile fared best in 1999, when its income was lifted by $8.3 \%$ by the parental allowance benefit, but the increase was $5.6 \%$ only in 2002 . The "other social support" category showed as a rather targeted benefit as well, but its analysis is complicated by its composite character.

Child allowances are rather problematic: they do distribute towards the poorest decile (rise of income by $6-8 \%$ ), but they keep boosting income of all income groups, which makes them unnecessarily expensive (see below). However, the budgetary cost of children allowances spend on the richer $50 \%$ of households did fall during the analysed period. While in 1999 more than $20 \%$ of all benefits went to the richer households, their share fell to $13-14 \%$ in $2000-2002$.

The illness and unemployment benefits are allegedly „insurance-based“ but due to the severe ceilings on these benefits, they resemble standard social security schemes. That is why we can assess their redistribution effects. Table 4 shows that unemployment benefits are better targeted of the two: they typically boost income of the poorest deciles by $1-2 \%$, and largely ignore the rest of income groups. IIIness benefits are much more spread (and expensive - see below), as they enhance the poorest income by $6-10 \%$, but the rest of population gets a $2-3 \%$ bonus as well.

Table 4 also shows the distribution impact of tax deductible allowances. We can see that the impact of tax allowances was decreasing in the period $1999-2002$. While they boosted the poorest decile's income by $12 \%$ in 1999 , the boost fell to 
Table 4

Income Boosts Received by Different Deciles from Various Schemes per Individual and per Year 1999 - 2002 (in \%)

\begin{tabular}{|c|c|c|c|c|c|c|c|c|}
\hline & $\begin{array}{c}\text { Child } \\
\text { allowan- } \\
\text { ces }\end{array}$ & $\begin{array}{l}\text { Social } \\
\text { supple- } \\
\text { ment }\end{array}$ & $\begin{array}{l}\text { Parental } \\
\text { allowan- } \\
\text { ces }\end{array}$ & $\begin{array}{c}\text { Other } \\
\text { social } \\
\text { support }\end{array}$ & $\begin{array}{c}\text { Unemploy- } \\
\text { ment } \\
\text { benefits }\end{array}$ & $\begin{array}{c}\text { Illness } \\
\text { benefits }\end{array}$ & TOTAL & $\begin{array}{c}\text { Tax de- } \\
\text { ductible } \\
\text { allowance }\end{array}$ \\
\hline \multicolumn{9}{|l|}{1999 data } \\
\hline Decile 1 & 7.6 & 6.1 & 8.3 & 3.6 & 1.8 & 6.4 & 33.8 & 11.8 \\
\hline Decile 2 & 4.7 & 1.7 & 5.3 & 1.3 & 1.3 & 4.8 & 19.2 & 9.0 \\
\hline Decile 3 & 3.4 & 0.7 & 3.1 & 0.5 & 0.6 & 3.6 & 12.1 & 8.2 \\
\hline Decile 4 & 3.0 & 0.2 & 1.4 & 0.5 & 0.2 & 3.0 & 8.4 & 7.6 \\
\hline Decile 5 & 2.2 & 0.1 & 0.7 & 0.3 & 0.3 & 3.0 & 6.6 & 6.8 \\
\hline Decile 6 & 1.7 & 0.0 & 0.4 & 0.1 & 0.4 & 2.0 & 4.8 & 6.4 \\
\hline Decile 7 & 0.9 & 0.0 & 0.2 & 0.1 & 0.2 & 1.9 & 3.4 & 6.0 \\
\hline Decile 8 & 0.4 & 0.0 & 0.1 & 0.1 & 0.2 & 1.9 & 2.7 & 5.4 \\
\hline Decile 9 & 0.2 & 0.0 & 0.2 & 0.1 & 0.1 & 1.7 & 2.3 & 4.8 \\
\hline Decile 10 & 0.0 & 0.0 & 0.1 & 0.0 & 0.0 & 0.6 & 0.8 & 3.9 \\
\hline \multicolumn{9}{|l|}{2000 data } \\
\hline Decile 1 & 7.9 & 6.0 & 8.1 & 4.5 & 1.6 & 9.8 & 39.1 & 8.9 \\
\hline Decile 2 & 3.3 & 0.9 & 3.4 & 0.7 & 0.4 & 3.4 & 12.4 & 5.2 \\
\hline Decile 3 & 2.6 & 0.3 & 2.3 & 0.4 & 0.8 & 3.7 & 10.3 & 5.2 \\
\hline Decile 4 & 2.3 & 0.1 & 0.7 & 0.3 & 0.6 & 3.1 & 7.2 & 5.3 \\
\hline Decile 5 & 1.6 & 0.0 & 0.3 & 0.3 & 0.3 & 2.6 & 5.3 & 5.0 \\
\hline Decile 6 & 1.1 & 0.0 & 0.3 & 0.1 & 0.3 & 1.8 & 3.8 & 4.9 \\
\hline Decile 7 & 0.7 & 0.0 & 0.2 & 0.1 & 0.2 & 2.5 & 3.8 & 4.5 \\
\hline Decile 8 & 0.3 & 0.0 & 0.1 & 0.1 & 0.2 & 2.4 & 3.3 & 4.1 \\
\hline Decile 9 & 0.1 & 0.0 & 0.0 & 0.0 & 0.2 & 1.6 & 2.0 & 4.0 \\
\hline Decile 10 & 0.0 & 0.0 & 0.1 & 0.0 & 0.1 & 0.9 & 1.1 & 3.4 \\
\hline \multicolumn{9}{|l|}{2001 data } \\
\hline Decile 1 & 6.0 & 4.9 & 6.3 & 3.2 & 1.3 & 6.9 & 29.3 & 8.3 \\
\hline Decile 2 & 3.6 & 1.1 & 3.0 & 1.1 & 0.5 & 3.9 & 13.6 & 5.6 \\
\hline Decile 3 & 2.1 & 0.1 & 1.8 & 0.3 & 0.5 & 2.6 & 7.8 & 4.8 \\
\hline Decile 4 & 1.8 & 0.1 & 0.8 & 0.2 & 0.4 & 2.4 & 5.7 & 4.4 \\
\hline Decile 5 & 1.3 & 0.0 & 0.6 & 0.2 & 0.4 & 1.9 & 4.4 & 3.8 \\
\hline Decile 6 & 0.9 & 0.0 & 0.1 & 0.1 & 0.2 & 1.8 & 3.1 & 3.8 \\
\hline Decile 7 & 0.4 & 0.0 & 0.1 & 0.1 & 0.2 & 1.9 & 2.9 & 3.6 \\
\hline Decile 8 & 0.3 & 0.0 & 0.1 & 0.0 & 0.1 & 1.5 & 2.0 & 3.3 \\
\hline Decile 9 & 0.1 & 0.0 & 0.0 & 0.0 & 0.1 & 1.1 & 1.3 & 3.1 \\
\hline Decile 10 & 0.0 & 0.0 & 0.0 & 0.0 & 0.0 & 0.7 & 0.8 & 2.6 \\
\hline \multicolumn{9}{|l|}{2002 data } \\
\hline Decile 1 & 6.0 & 4.6 & 5.2 & 3.4 & 1.8 & 9.2 & 31.0 & 7.5 \\
\hline Decile 2 & 3.7 & 1.4 & 3.3 & 1.4 & 0.7 & 5.6 & 16.3 & 5.4 \\
\hline Decile 3 & 2.6 & 0.5 & 1.8 & 0.9 & 0.7 & 3.6 & 10.4 & 4.6 \\
\hline Decile 4 & 2.0 & 0.2 & 1.2 & 0.5 & 0.7 & 3.0 & 7.7 & 4.2 \\
\hline Decile 5 & 1.4 & 0.0 & 0.9 & 0.2 & 0.6 & 3.0 & 6.3 & 3.9 \\
\hline Decile 6 & 1.1 & 0.0 & 0.4 & 0.3 & 0.4 & 2.1 & 4.3 & 3.7 \\
\hline Decile 7 & 0.7 & 0.0 & 0.3 & 0.2 & 0.2 & 2.1 & 3.6 & 3.4 \\
\hline Decile 8 & 0.4 & 0.0 & 0.2 & 0.1 & 0.3 & 1.7 & 2.5 & 3.1 \\
\hline Decile 9 & 0.2 & 0.0 & 0.1 & 0.0 & 0.1 & 1.6 & 2.0 & 3.0 \\
\hline Decile 10 & 0.0 & 0.0 & 0.0 & 0.0 & 0.0 & 0.8 & 0.9 & 2.5 \\
\hline
\end{tabular}

Source: Authors' calculations. 
$7.5 \%$ in 2002 and all deciles shared the same development. Tax allowances are also, by their construction, less progressive than social benefits. The middle deciles' incomes were increased by $4-6 \%$ and the richest decile gained $4 \%$ in 1999 and only $2.5 \%$ in 2002. In absolute terms, though, the richest decile is the winner as the average gain from tax credits per person in this decile was almost CZK 8,000 in 1999 and more than CZK 9,000 in 2002. The gain falls to about CZK 5,000 for the poorest decile for the whole period.

\section{Budget Costs of the Social System Redistribu- tion}

The Czech social security system has considerable costs that burden the public budgets. The Table 5 shows that the total costs of various social programmes increased from CZK 53 bill. in 1999 to CZK 68 bill. in 2002, i.e. from less than $3 \%$ to $3.3 \%$ of GDP. Tax deductible allowance represents tax expenditure of further CZK $49-52$ bill., i.e. about $2.5 \%$ of GDP. It is thus of utmost importance to analyse what impact these costs have on the income redistribution. We assess this issue by breaking up the total costs of various programmes as they are distributed to the ten deciles of households. Funds spent on the lowest decile should have the highest "social marginal utility", while funds distributed towards the well-off deciles are thought to be less significant. Of course, this is not to say that all money distributed to, say, five upper deciles are wasted. Some of the money will always end up with the rich. Also, in some cases comprehensible means testing would be administratively unattainable or too expensive. However, some of transfers to the well offs can be eliminated or scaled down without any apparent loss of welfare.

The most expensive social scheme in the Table 5 is the illness benefit on which CZK 28 bill. was spent in 2002. The poorest decile gets most of the money distributed via the scheme (about $25 \%$ ), but significant sums (about one third) go to the well-off deciles and even to the richest decile. A radical reform of the system, perhaps based on private insurance could save almost $34 \%$ of the costs (CZK 10 bill. in 2002 that went toward the five richest deciles that surely do not need state assistance). The reform would, though, require a shift in the government policy and would not be administratively easy.

The second most expensive programme is the notorious child allowance scheme on which CZK $12-13$ bill. is spent annually. We discussed its arithmetic in the chapter 2, and the Table 5 only underlines the arguments raised there: the programme spends about $20 \%$ on the richer half of the Czech households. These funds may be saved without much complication, as the programme is already (poorly) meanstested, so by changing the coefficient of eligibility the government would save CZK $2-3$ bill.

Other programmes are less costly and generally better targeted. Both parental allowances and social supplements are concentrated on the poorest decile and funds spent on well-off households are probably unnecessary consequence of the programme's administration. Similarly, unemployment benefits go predominantly towards the poorest (two poorest deciles receive almost $50 \%$ of all benefits).

Taken together, the poorest decile gets about $40 \%$ of the total social programmes costs (less in 1999, more in 2000). Two poorest deciles, an alternative target group, received $46 \%$ of the total funds distributed in 1999 and more than half of the funds in $2000-2002$ period. Should the Czech government target three deciles, as would the 1.8 of MLS threshold suggest, the share of funds spent on these three deciles was $59 \%$ in 1999, $68 \%$ in 2000, $67 \%$ in 2001 and $62 \%$ in 2002. Whether this share is appropriate remains an open issue. 
Table 5

Budget Costs of Redistribution to Different Deciles (CZK bill.)

\begin{tabular}{|c|c|c|c|c|c|c|c|c|}
\hline & $\begin{array}{l}\text { Child } \\
\text { allowan- } \\
\text { ces }\end{array}$ & $\begin{array}{l}\text { Social } \\
\text { supple- } \\
\text { ment }\end{array}$ & $\begin{array}{l}\text { Parental } \\
\text { allowan- } \\
\text { ces }\end{array}$ & $\begin{array}{c}\text { Other so- } \\
\text { cial assis- } \\
\text { tance }\end{array}$ & $\begin{array}{l}\text { Illness } \\
\text { benefits }\end{array}$ & $\begin{array}{c}\text { Unemploy- } \\
\text { ment } \\
\text { benefits }\end{array}$ & TOTAL & $\begin{array}{c}\text { Tax de- } \\
\text { ductible } \\
\text { allowance }\end{array}$ \\
\hline \multicolumn{9}{|l|}{1999} \\
\hline Decile 1 & 2,588 & 3,727 & 2,430 & 1,661 & 2,301 & 1,456 & 14,164 & 4,904 \\
\hline Decile 2 & 2,206 & 1,416 & 2,062 & 764 & 2,275 & 1,219 & 9,942 & 4,843 \\
\hline Decile 3 & 1,777 & 657 & 1,348 & 350 & 1,861 & 765 & 6,759 & 4,785 \\
\hline Decile 4 & 1,883 & 224 & 779 & 383 & 1,734 & 284 & 5,286 & 5,219 \\
\hline Decile 5 & 1,394 & 134 & 389 & 281 & 1,858 & 420 & 4,476 & 4,817 \\
\hline Decile 6 & 1,310 & 21 & 242 & 141 & 1,367 & 644 & 3,725 & 5,210 \\
\hline Decile 7 & 750 & 13 & 150 & 100 & 1,457 & 300 & 2,770 & 4,956 \\
\hline Decile 8 & 351 & 23 & 63 & 107 & 1,409 & 257 & 2,211 & 4,344 \\
\hline Decile 9 & 190 & 21 & 167 & 172 & 1,452 & 284 & 2,285 & 4,499 \\
\hline Decile 10 & 50 & 15 & 88 & 41 & 753 & 71 & 1,018 & 4,879 \\
\hline TOTAL & 12,500 & 6,251 & 7,718 & 4,000 & 16,467 & 5,700 & 52,636 & 48,456 \\
\hline \multicolumn{9}{|l|}{2000} \\
\hline Decile 1 & 5,978 & 5,399 & 4,649 & 3,730 & 8,261 & 2,192 & 30,209 & 8,534 \\
\hline Decile 2 & 1,618 & 512 & 1,298 & 390 & 2,168 & 405 & 6,392 & 3,596 \\
\hline Decile 3 & 1,300 & 177 & 866 & 219 & 2,086 & 666 & 5,314 & 3,711 \\
\hline Decile 4 & 1,269 & 59 & 292 & 225 & 2,060 & 614 & 4,519 & 3,956 \\
\hline Decile 5 & 972 & 17 & 147 & 252 & 1,739 & 415 & 3,542 & 4,107 \\
\hline Decile 6 & 738 & 11 & 161 & 63 & 1,320 & 320 & 2,614 & 4,455 \\
\hline Decile 7 & 475 & 10 & 112 & 73 & 1,810 & 239 & 2,718 & 4,522 \\
\hline Decile 8 & 234 & 13 & 92 & 37 & 1,775 & 376 & 2,526 & 4,637 \\
\hline Decile 9 & 121 & 1 & 18 & 32 & 1,417 & 305 & 1,895 & 5,145 \\
\hline Decile 10 & 44 & 1 & 57 & 16 & 1,081 & 146 & 1,346 & 6,099 \\
\hline TOTAL & 12,748 & 6,199 & 7,692 & 5,038 & 23,716 & 5,680 & 61,073 & 48,762 \\
\hline \multicolumn{9}{|l|}{2001} \\
\hline Decile 1 & 5,433 & 5,142 & 4,369 & 4,111 & 7,735 & 2,236 & 29,027 & 9,407 \\
\hline Decile 2 & 2,096 & 676 & 1,362 & 820 & 3,094 & 614 & 8,661 & 4,271 \\
\hline Decile 3 & 1,311 & 101 & 831 & 267 & 2,054 & 565 & 5,130 & 4,022 \\
\hline Decile 4 & 1,247 & 59 & 437 & 207 & 2,105 & 407 & 4,462 & 4,082 \\
\hline Decile 5 & 1,017 & 30 & 330 & 225 & 1,938 & 509 & 4,049 & 4,070 \\
\hline Decile 6 & 763 & 8 & 90 & 156 & 2,075 & 237 & 3,330 & 4,583 \\
\hline Decile 7 & 424 & 0 & 97 & 182 & 2,125 & 266 & 3,095 & 4,778 \\
\hline Decile 8 & 328 & 7 & 93 & 33 & 1,826 & 182 & 2,469 & 5,041 \\
\hline Decile 9 & 106 & 2 & 48 & 31 & 1,475 & 191 & 1,853 & 5,514 \\
\hline Decile 10 & 73 & 16 & 44 & 23 & 1,288 & 21 & 1,465 & 6,156 \\
\hline TOTAL & 12,799 & 6,041 & 7,701 & 6,055 & 25,716 & 5,229 & 63,541 & 51,925 \\
\hline \multicolumn{9}{|l|}{2002} \\
\hline Decile 1 & 4,749 & 4,653 & 3,478 & 3,179 & 7,832 & 2,061 & 25,951 & 8,012 \\
\hline Decile 2 & 2,249 & 1,040 & 1,676 & 960 & 3,394 & 643 & 9,962 & 4,616 \\
\hline Decile 3 & 1,571 & 378 & 909 & 700 & 2,411 & 661 & 6,629 & 3,937 \\
\hline Decile 4 & 1,372 & 116 & 648 & 412 & 2,500 & 764 & 5,813 & 4,103 \\
\hline Decile 5 & 1,080 & 29 & 589 & 204 & 2,596 & 623 & 5,120 & 4,341 \\
\hline Decile 6 & 967 & 10 & 253 & 268 & 1,966 & 407 & 3,872 & 4,590 \\
\hline Decile 7 & 718 & 39 & 197 & 220 & 2,219 & 324 & 3,716 & 4,766 \\
\hline Decile 8 & 400 & 6 & 154 & 56 & 1,999 & 456 & 3,071 & 5,125 \\
\hline Decile 9 & 196 & 0 & 74 & 30 & 2,020 & 209 & 2,529 & 5,648 \\
\hline Decile 10 & 50 & 0 & 45 & 27 & 1,381 & 62 & 1,565 & 6,619 \\
\hline TOTAL & 13,353 & 6,271 & 8,022 & 6,055 & 28,318 & 6,210 & 68,229 & 51,758 \\
\hline
\end{tabular}

Source: Authors' calculations. 
The budget cost of the tax deductible allowances were distributed most equally across all income deciles. Still the poorest decile's cost of around CZK 8 bill. is the highest. However, the second highest costs are associated with the richest decile: around CZK 6 bill. are handed to the richest households in the Czech Republic see Table 5.

\section{Measuring Efficiency of Social Programmes}

The efficiency of individual programmes is very difficult to measure, because social projects have different goals and are devoted to different social groups. The commonly used approach, which is also adopted in this paper, is to concentrate on budgetary cost of individual programmes and its distribution across income groups. This approach gives us interesting information about individual programmes but it does not give us tool for their mutual comparison.

We have tried to construct a unique efficiency measure for all social programmes. Our basic assumption is that the main objective of social policy is to help poorest groups of population, i.e. lowest income group decile. We look at how much it costs to lift income of a respective target group by one percentage point. If, for example child allowances, with the total costs of CZK 12.5 bill. in 1999, lift income of the poorest decile by $7.6 \%$, the cost of a $1 \%$ increase is CZK 1.6 bill. If, on the other hand, parental allowances, with the total costs of CZK 8 bill. in 2002, boost income of the poorest deciles by $5.2 \%$, the costs of $1 \%$ increase is CZK 1.5 bill (see Table 6).

On this measure, parental allowances and social supplement are the most efficient. Parental allowances were the most efficient in $1999-2001$ : it cost less than a billion to lift the poorest decile's income by $1 \%$ by this benefit in 1999 and 2000 . However, the parental allowances became less efficient in 2002 , as their cost jumped to 1.5 bill. per percentage point of income of the poorest deciles. Social supplement programme needed a little more than one billion to deliver the same boost in 1999 and 2000. This programme became the most efficient in 2002: while its costs did increase, they rose to 1.35 bill. only.

Social supplement is, by definition, targeted at the poorest households and should serve as a benchmark of efficiency for other programmes. Relative efficiency of parental allowance scheme follows from the fact that families with children have usually lower than average income and it is thus "cheaper" to lift their income by $1 \%$. If one parent stays at home to look after children and so has right to receive parental allowance family income falls to the lowest income groups. ${ }^{14)}$

Table 6

The Costs to Move up Target Groups' Income by $1 \%$ (in CZK bill.)

\begin{tabular}{|l|c|c|c|c|c|c|c|}
\hline & $\begin{array}{c}\text { Children } \\
\text { allowances }\end{array}$ & $\begin{array}{c}\text { Social } \\
\text { supple- } \\
\text { ment }\end{array}$ & $\begin{array}{c}\text { Parental } \\
\text { allowan- } \\
\text { ces }\end{array}$ & $\begin{array}{c}\text { Unemploy- } \\
\text { ment } \\
\text { benefits }\end{array}$ & $\begin{array}{c}\text { Illness } \\
\text { benefits }\end{array}$ & Average & $\begin{array}{c}\text { Tax de- } \\
\text { ductible } \\
\text { allowance }\end{array}$ \\
\hline 1999 & 1.643 & 1.020 & 0.927 & 3.206 & 2.593 & 1.557 & 4.116 \\
\hline 2000 & 1.615 & 1.026 & 0.951 & 3.574 & 2.412 & 1.562 & 5.454 \\
\hline 2001 & 2.120 & 1.230 & 1.229 & 3.909 & 3.745 & 2.169 & 6.251 \\
\hline 2002 & 2.209 & 1.355 & 1.546 & 3.508 & 3.077 & 2.201 & 6.880 \\
\hline
\end{tabular}

14) However, in reality some families report only one parent income while the other parent has also its own income. 
Children allowances fare worse with costs of CZK 1.6 bill. in 1999 and more than 2.2 bill. in 2002. Programmes, which are based on "social insurance" concept, are less efficient to increase income of the poorest population. Unemployment and illness benefits both needed more than CZK 3 bill. to increase income of lowest decile by $1 \%$ in 2002 .

Tax allowances are the least efficient programme, measured by our proxy. It cost as much as CZK 6 bill. to lift income of the poorest decile by $1 \%$. However, as noted above, tax deductions have other merits as well. Most importantly, they do not discourage from work and are cheaper to administer.

\section{Conclusions}

Our analysis of main social benefits and tax credits impact on household income distribution, which is monitored by Household Budget Surveys, has brought several results. The first result seems to be that targeting of majority of social programmes is quite good. More than one third of all expenses (38\% in 2002) in relation to six studied social benefits (child allowance, parental allowance, social supplement, other social support, illness benefit, and unemployment benefit) goes to households in the lowest income decile. Three fourth of all expenses goes to households in the lower half of income spectrum. If we take as benchmark probably the best targeted programme - i.e. social supplement - targeting could be improved in a way that upper half of richer households would get only $10 \%$ instead of $25 \%$ of social benefits. If implemented, this would save about $0.5 \%$ GDP from the state budget without affecting households with lower than average income.

We also constructed a proxy measuring efficiency of various social programmes. If we assume that the government's social welfare function gives dominant importance to the poorest decile of households, it should strive to increase its income by the most efficient programmes, i.e. social supplement and parental allowances. However, when we look at the budgetary developments in the $1999-2002$, the Czech government aggressively increased spending on social programmes that are least efficient. Expenditures on illness benefits jumped by more than $70 \%$ in the four-year period and expenditures on unemployment benefits increased by $9 \%$. These are the least efficient programmes.

Expenditures on most efficient programmes - social supplement and parental allowances - stagnated. Social supplement expenditures remained constant even in nominal terms, while parental allowances expenditures grew by $4 \%$ only. However, the government's welfare function remains unspecified so we can only guess which programmes best reflect government's priorities.

\section{References}

Bezděk, V. (2005), "The Public Pension System in the Czech Republic from the Point of View of Public Finance," Kunitachi, Hitotsubashi University, Institute of Economic Research PIE Discussion Paper. Erbenová, M., Šorm, V., Terrell, K. (1996), "Work Incentive and Other Effects of Social Assistance and Unemployment Benefit Policy in the Czech Republic." Paris, OECD Seminar.

Haan, P., Steiner, V. (2004), "Distributional and Fiscal Effects of German Tax Reform 2004: A Behavioral Microsimulation Analysis." Berlin, DIW Working Paper.

Jelínek, T., Schneider, O. (1997), "Time for Pension Reform in the Czech Republic; Pension Trouble Is Brewing in the Visegrad Countries." Transitions, 4 (1), pp. 77-103.

Newberry, D. M. G. (ed.) (1995), Tax and Benefit Reform in Central and Eastern Europe. London, CEPR. 
OECD (1995), Review of Labor Market and Social Policy in the Czech Republic. Paris: Organization for Economic Cooperation and Development.

(2001), Economic Review of the Czech Republic. Paris: Organization for Economic Cooperation and Development.

Průša, L. (2001), "Social Benefits and Taxes in 1995 - 2000 and beyond" (in Czech). Finance a úvěr, 51 (12), pp. 658-675.

Schneider, O. (2003), "Czech Public Budgets in the 1990s - Roots of a Crisis" (in Czech). Prague, Institute of Economic Studies Working Paper 30.

(2004), Protecting People While Enhancing Work Incentives: The Role of the Welfare System in Czech Republic: Ageing and Employment Policies. Paris: OECD.

Schneider, O., Salí, M., Zápal, J. (2003), "Labour and Capital Taxation - Theory and Application to the Czech Economy" (in Czech). Finance a úvěr, 53 (11/12), pp. 539-561.

Schneider, O., Jelínek, T. (2001), "Impact of Czech Social Security System and Tax Deductible Allowance on the Income Distribution" (in Czech). Finance a úvěr, 51 (12), pp. 639-657.

Schneider, O., Štěpánek, P. (2001), "A Looming Financial Crisis in the Czech Republic," in Dabrowski, M., Rostowski, J., eds., The Eastern Enlargement of the EU. London: Kluwer Academic Publishers, pp. 151-168.

Večerník, J. (1996), Markets and People - The Czech Reform Experience in a Comparative Perspective, Aldershot: Avebury.

(1998), Citizen and Market Economy - Incomes, Inequality and Political Positions in the Czech Society (in Czech). Prague: Lidové noviny.

Večerník, J., Matějů, P. (1999), Ten Years of Rebuilding Capitalism: Czech Society After 1989. Prague: Academia.

WB (2001), Czech Republic: Enhancing the Prospects for Growth with Fiscal Stability. Washington: World Bank. 